\title{
Morphological Examination of the Accessory Sex Glands of the Barki Goat (Capra hircus)
}

\author{
Mohamed M.A. Abumandour, ${ }^{1}$ Mohamed Alsafy, ${ }^{1}$ Ashraf Karkoura, ${ }^{1}$ Raafat El-Bakary1Manal Amir Seif ${ }^{2}$ \\ 'Department of Anatomy and Embryology, Faculty of Veterinary Medicine, Alexandria University, Alexandria, Egypt \\ ${ }^{2}$ Department of Anatomy and Embryology, Faculty of Veterinary Medicine, Matrouh University, Matrouh, Egypt
}

Disclose and conflicts of interest: none to be declared by all authors

\begin{abstract}
Introduction: The goal of the present investigation is to describe the accessory sex glands of the Barki goat, grossly, by using the histological technique. The Barki goat have four sex glands: ampullary, vesicular, prostate, and bulbourethral. The ampullary gland is an enlargement of the terminal part of the ductus difference; its glandular part has branched tubuloalveolar glands, and its secretory alveoli are lined with a pseudostratified epitheliumcomposed of cuboidal to columnar cells. The vesicular gland takes the appearance of a cluster of grapes, and the left vesicular gland is enlarged and higher than the right one. It presents as a lobulated tubulo-alveolar gland with wide intralobular space, which contains a secretory unit that is lined with pseudo-stratified columnar epithelium, while the interlobular ductules are lined with the stratified epithelium, and the interlobular duct is lined with simple cuboidal epithelium; moreover, the epithelium lining of the secretory part consists of tall columnar cells. The prostate gland consists of the disseminated part (pars disseminate), and it is enclosed by a connective tissue capsule, which is thin dorsally, thick laterally, and reduced in thickness ventrally. The prostatic acini are lined with simple cuboidal epithelium. The bulbourethral gland is similar in size to a walnut and is surrounded by a capsule; there are interlobular connective tissue septa that divide the gland into lobes and lobules of different sizes. The bulbourethral gland contains secretory units that are lined with mucous, tall columnar epithelium with basally located nuclei, and whose eosinophilic cytoplasm contain granular secretion.
\end{abstract}

Keywords: Ampullary gland; Vesicular gland; Prostate gland; Bulbourethral gland; Goat

\section{Introduction}

The ruminantanatomy was generally concentrated on the bovine, particularly the ox, with limited comparative points to small ruminants, especially the goat. The goat belongs to the subfamily Caprinae, which is part of the Bovidae family, in the sub-order Ruminantia of the order Artiodactyla. In Egypt, the goat is considered as an important source of meat, milk, and hair. The male goat is a very familiar animal in the Egyptian farms. There are about 7 to 10 goat breeds in Egypt, such as Zaraibi, Barki (Sahrawi), Wahati, Sharkawi, and Black Sinai. ${ }^{1}$ The three major breeds in Egypt are Ossimi, Rahmani, and Barki, which are characterized by a fat tail, a fleece of coarse wool, and their small-to-medium size. ${ }^{1}$

There goats have four accessory sex glands; prostate, seminal vesicle, bulbourethral gland, and ampullary gland, as reported by ${ }^{2-9}$ while Pérez et $a l^{10}$ reported that the pampas deer carry only three accessory sex glands: prostate, vesicular, and the ampullary gland. The lesser anteater also carries only three accessory sex glands: prostate, seminal vesicle, and bulbourethral glands, as noted by Rossi et al. ${ }^{11}$

The purpose of the present work is to describe the anatomical position and appearance of the accessory sex glands of the Barki (Sahrawi) male goat as well as the microscopic structure of theses glands as there is a little available information published about this topic. Then, we conducted a comparison between the obtained data and the previously published anatomical data about the accessory sex glands. The study of the accessory sex gland of the male goat is very important due to its significant role in the fertility rate.

\section{Materials and Methods}

\section{Animals}

The present work was performed on 8 apparently healthy Barki male goats, whose weight was 25 to $30 \mathrm{~kg}$ and that were between 1 and 2 years old. The Barki male goats were collected from the goat farms in from the government of Matrouh and 
transported to the anatomical laboratory in the anatomy and embryology department of the Faculty of Veterinary Medicine at Alexandria University. The collected goats were treated according to the rules of the committee on Animal Welfare and Ethics of the Faculty of Veterinary Science of Alexandria University and according to the Egyptian laws.

\section{Gross Anatomy}

Four Barki male bucks were used in the gross morphological descriptions after their sedation with intramuscular $(\mathrm{I} / \mathrm{M})$ injection of $2 \%$ xylazine hydrochloride $(\mathrm{Hcl})(0.2 \mathrm{mg} / \mathrm{kg}$ of body weight) and atropine $(0.04 \mathrm{mg} / \mathrm{kg})$. Then, theses goats were anaesthetized by intravenous (I/V) injection of ketamine $(5 \mathrm{mg} / \mathrm{kg})$. After that, the goats were injected with heparin (1,000 IU) to obtain bleeding and prevent blood coagulation. Then, the goats sacrificed by bleeding through the common carotid artery received an injection of $10 \%$ formalin, after which they were stored for 2 weeks in formalin $10 \%$. The cadavers received injections in several sites of the body and on the pelvic cavity using the ordinary preservation solution (10\% formalin, $2 \%$ phenol, and $1 \%$ glycerin). The nomenclature used in this work is in accordance with the Nomina Anatomica Veterinaria. ${ }^{12}$

\section{Computed Tomography (CT) Scans}

Two goats were used for carrying the CT scans after the normal physical examination and were anaesthetized by using the combination of ketamine hydrate $(0.5-2 \mathrm{mg} / \mathrm{kg}$ of body weight) and $2 \%$ xylazine $\mathrm{Hcl}(1-3 \mathrm{mg} / \mathrm{Kg}$ of body weight). The cadavers were immediately taken to the CT center and fixed in the sternal recumbency position and, then, serially sectioned using the CT-W45010A Hitachi CT scanner (Hitachi, Chiyoda, Tokyo, Japan) and this CT machine called Asteion Super 4 Multi-slice 4 CT apparatus (Toshiba, Minato, Tokyo, Japan) at $120 \mathrm{KV}$ and $\sim 200 \mathrm{MA}$ Q11, the windows width and level (W/L) : 2,000/250Q12) to examine the accessory male sex reproductive glands. The thickness of the sections was $0.5 \mathrm{~cm}$ in the interval between the cross section from the level of the last lumbar to the $4^{\text {th }}$ caudal vertebrae. The CT images helped in the identification of the structures that were located between the levels of the $5^{\text {th }}$ lumbar and the $4^{\text {th }}$ caudal vertebrae.

In order to obtain bone window images with good resolution, the $\mathrm{CT}$ machine was set to a window width of 200 Hounsfield and a window level of 1,600 Hounsfield units. However, in the soft tissue, we set the apparatus to a windows width of 30 Hounsfield units, and a window level of 290 Hounsfield units.

A $3^{\text {rd }}$ generation single-slice CT scanner (Asteion Super 4 Multi-slice 4 CT apparatus [Toshiba]) was used for all procedures. The helical scan mode was used with the following parameters: $120 \mathrm{kVp}$, $130 \mathrm{~mA}, 1.0$ second scan time, slice thickness of 5 $\mathrm{mm}$, and 5-mm table advancement. The standard acquisition preset of a $25-\mathrm{cm}$ field of view, matrix of 512512 pixels, bone reconstruction algorithm, and WWQ of 300 and WL of 1,000 were used. The raw dataset was retro-reconstructed to a slice thickness of $0.3 \mathrm{~mm}$. To obtain better reconstruction images, the overlapping technique, with slice thickness of $5 \mathrm{~mm}$ and $3-\mathrm{mm}$ table advancement, pitch of 0.6 Q15, (X-ray beam in overlapping) was also used. Images were visualized using the picture archiving and communication system (PACS) software OsiriX DICOM Viewer (Pixmeo SARL, Bernex, Geneva, Switzerland), for transverse scanning, multiplanar reformatting (MPR), and 3D rendering reconstruction.

\section{Histological Observations}

Two male goats were used for histological examinations. The accessory sex glands were removed from the freshly slaughtered male goats and then put on $10 \%$ normal buffer formalin solution, after which they were transported to the histological laboratory for the histological preparation of the slides (cutting and staining) to allow the examination of the specimen under the light microscope to know the characteristic points of each gland. Then, the samples were put in a $70 \%$ alcohol solution. After that, the samples were put in ascending grades of ethanol for dehydration, after which they were cleared by being immersed in xylene and embedded in paraffin wax. Samples sections of 5 um were cut by Leica rotatory microtome and mounted on glass slides. Finally, the paraffin sections were used for ordinary staining (H\&E). The histological techniques were carried according to Bancroft's Theory and Practice of Histological Techniques. ${ }^{13}$

\section{Results}

In all examined goats, we found four accessory sex glands (Glandulae genitales accessoriae); the paired ampulla of the ductus deferens (ampullary gland), the paired vesicular gland (Glandula vesicularis), the prostate (glandula prostatica), and the paired bulbourethral gland (Glandula bulbourethralis). All accessory sex glands were located along the pelvic urethra, and their ducts opened and emptied their 
secretion into the urethra.

\section{Ampulla Ductus Deferens (Ampullary Gland)}

The ampullary gland (Fig. 1A\LA and RA; 1B/ R.dd; 6A/4)isa glandular enlargement of the terminal part of the ductus difference. The length of the ampullary gland reaches $3.5 \pm 0.4 \mathrm{~cm}$ and the width reaches $0.5 \pm 0.12 \mathrm{~cm}$. The ampul-lary glands were directed ventrocaudally on the dorsal surface of the urinary bladder and attached to each other by the genital fold (Fig. 1A\GF).

The histological observations of the gland (Fig. 2) showed that they appeared to consist of the tunica mucosa, tunica muscularis, lamina propria, and tunica adventitia as well as some blood vessels. The glandular part contains branched tubuloalveolar glands. The secretory alveoli are lined with a pseudostratified epithelium composed of cuboidal to columnar cells with some basal cells.

\section{The Vesicular Gland (Glandula vesicularis)}

In all investigated goats, the paired vesicular gland (Fig. 1A\LV-RV; 1B/V; 6A/3) was located on the craniodorsal aspect of the neck of the urinary bladder (Vesica urinaria) and lateral to the ampullary glands. It can be easily identified by its appearance, which looks like a cluster of grapes, and it is also important to note that the left vesicular gland is enlarged and higher than the right one in the same goat.

The histological study clarifies that the vesicular gland (Fig. 3) is a lobulated tubuloalveolar gland with wide intralobular space or sinuses for storage
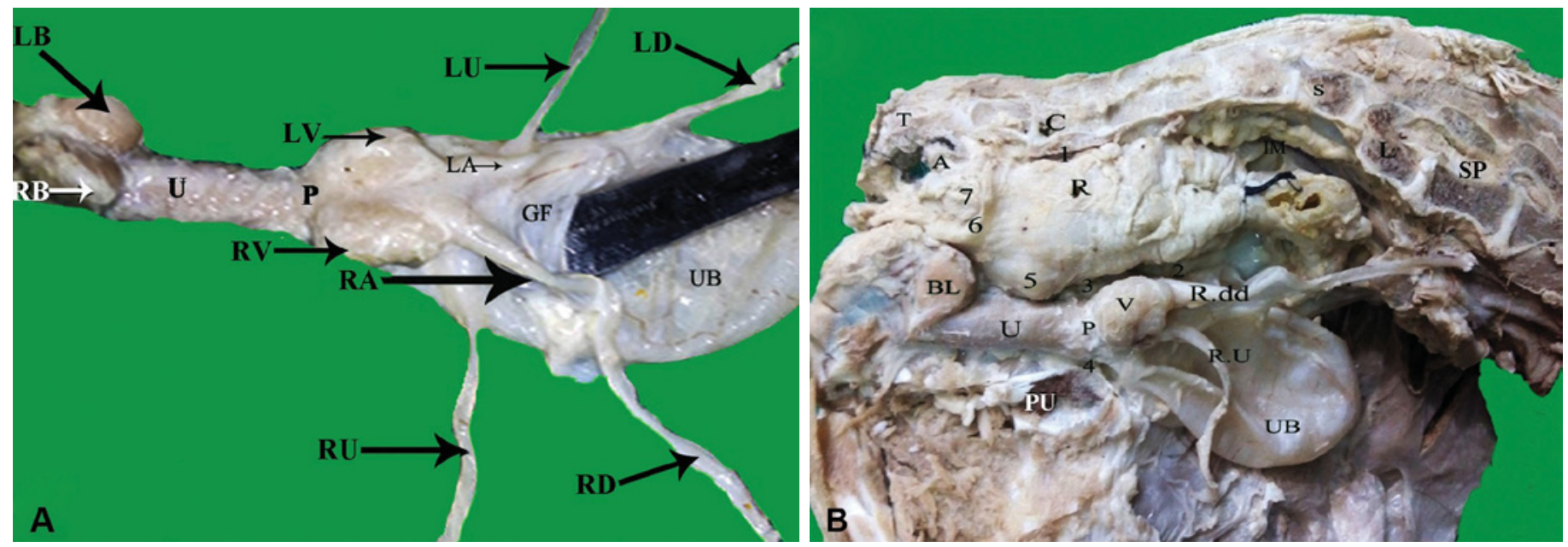

Figure 1. Morphological appearance of the position of the accessory sex reproductive glands of the buck: View (A) of the isolated genital organs with the accessory sex reproductive glands of the buck. Abbreviations: GF, genital fold; LA-RA, ampulla of ductus deference; LB-RB- left and right bulbourethral gland; LD-RD, left and right ductus deference; LU-RU, left and right ureter; LV- RV, left and right vesicular gland, P, prostate gland; U, urethra; UB, urinary bladder. View (B): represented the left side of the pelvic cavity showing the topography of the accessory sex reproductive glands of the buck: 1 - pararectal fossa, 2 - vesicogenital pouch, 3 - rectogenital pouch, 4 - pubovesical pouch, 5 - ampulla recti, 6 - muscle sphincter ani internus, 7 - muscle sphincter ani externus. Abbreviations: BL, bulbourethral gland; C, caudal vertebrae; IM, mesorectum; L, lumbar vertebrae; P, prostate gland; R, rectum; R.dd - right ampulla of ductus deference; RU, right ureter; S, sacral vertebrae; UB, urinary bladder; U, urethra; V, vesicular gland.
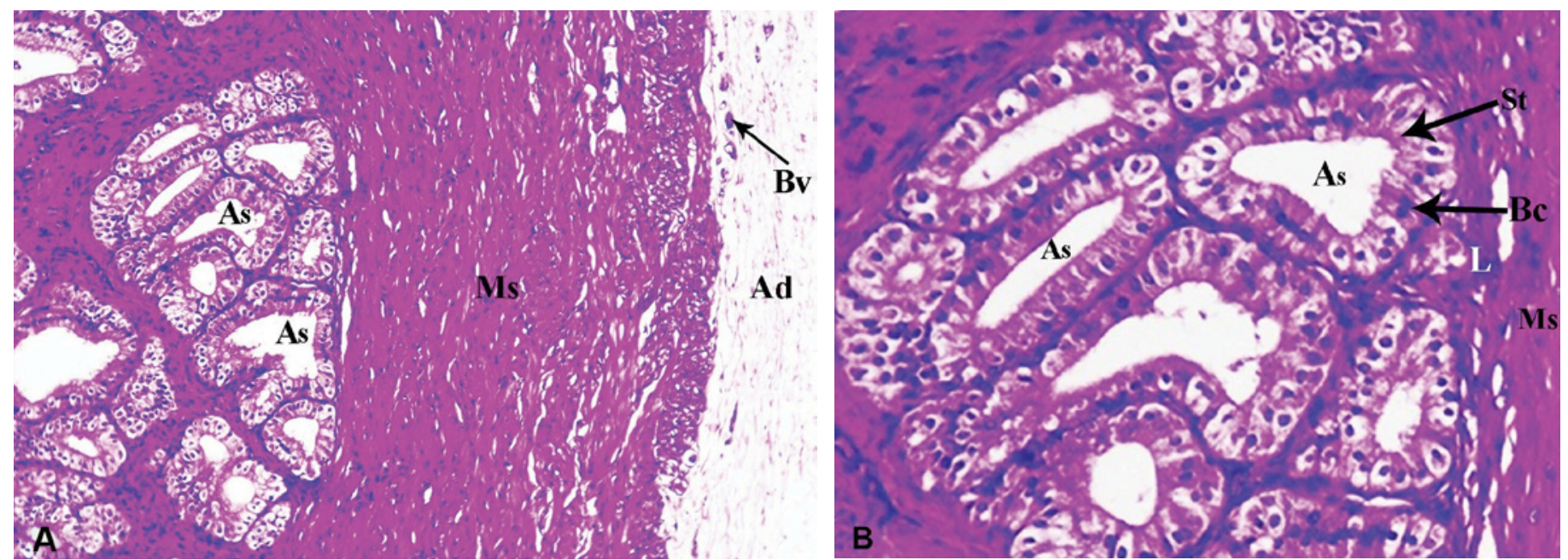

Figure 2. Micrograph (views A and B) of the ampullary gland of the adult buck showing: Alveoli (As); Tunica muscularis (Ms); Tunica adventitia (Ad); Blood vessels (BVs); Pseudo-stratified epithelium (St); Basal cell (BC); Lamina propria (L). hematoxylin and eosin (H\&E) x160. 

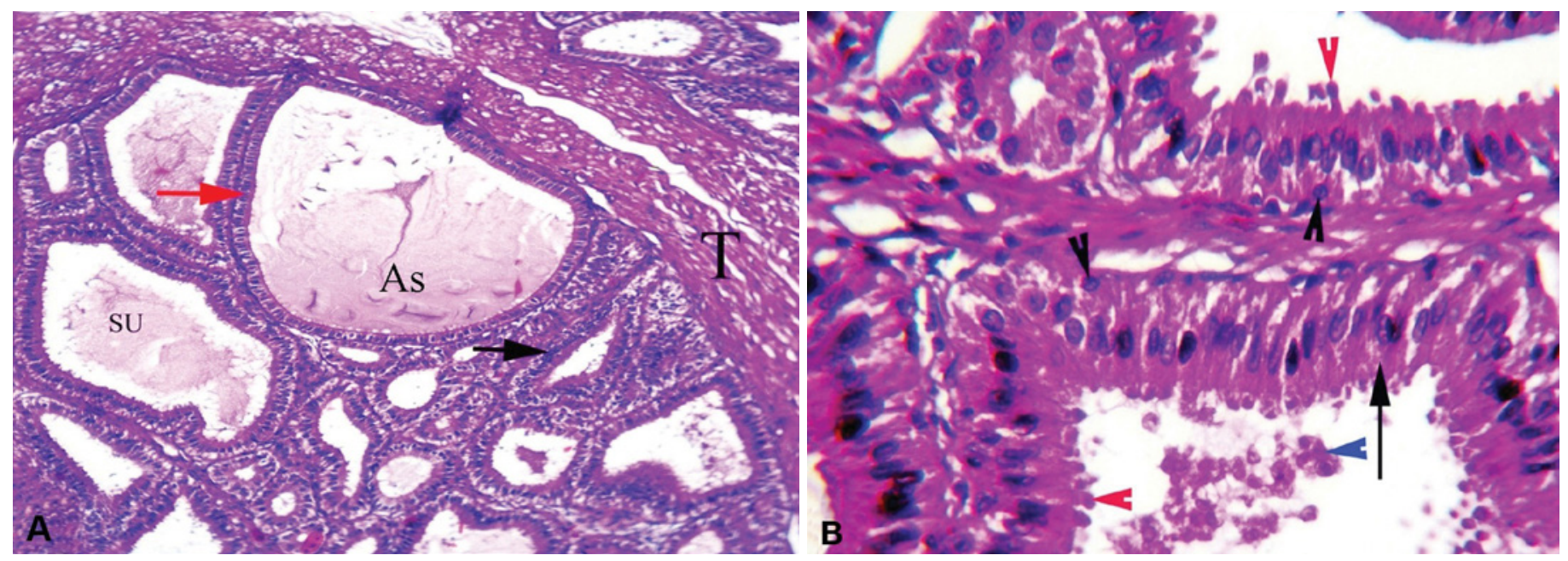

Figure 3. A cross section micrograph of the vesicular gland of the mature buck showing: View (A) clarify; SU- Secretory units lined by pseudo stratified columnar epithelium, intralobular ductules lined by stratified epithelium (black arrow) and intralobular duct lined by simple cuboidal epithelium (red arrow) with intraluminal eosinophilic secretion (As). Hematoxylin and eosin (H\&E) x160. View (B) clarify; the lining epithelium of secretory part consists of tall columnar cells

(arrow), Apical blebs of granular end pieces (red head arrows) and detached blebs in lamina Q17(blue head arrows), Small and spherical basal cells (black head arrows). H\&E x400.

of large amount of secretions. The gland contains a secretory unit, which is lined with pseudostratified columnar epithelium, and the interlobular ductules are lined by the stratified epithelium, while the interlobular duct is lined with simple cuboidal epitheliumwith intraluminal eosinophilic secretion. The epithelium lining of the secretory part consists of tall columnar cells, apical blebs of granular end pieces and detached blebs in lamina, and small and spherical basal cells.

The Prostate Gland (Glandula prostatica) In all the examined goats, the single prostate gland (Fig. 1/P; 6B/16) was present close to the junction of the vesicular gland at the pelvic region. It is constituted only of the disseminated part (pars disseminate). The pars dissemi-nate surrounds the pelvic urethra, which is covered by the male urethra.

According to the histological studies, the prostate gland (Fig. 4) is enclosed by a connective tissue capsule, which is thin dorsally, thick laterally, and reduced in thickness ventrally. The gland capsule is enveloped by a layer of skeletal muscle (urethralis muscle) that is surrounded by a layer of loose connective tissue extending from the capsule and descending into the parenchyma of the gland forming the interlobular connective tissue and dividing the gland into lobules. The glandular substance consists of numerous follicles that open into the elongated canal. The prostatic acini are lined by simple cuboidal epithelium.

\section{The BulbourethralGland(Glandula bulbourethralis) or Cowpers Gland}

In all the investigated goats, the paired

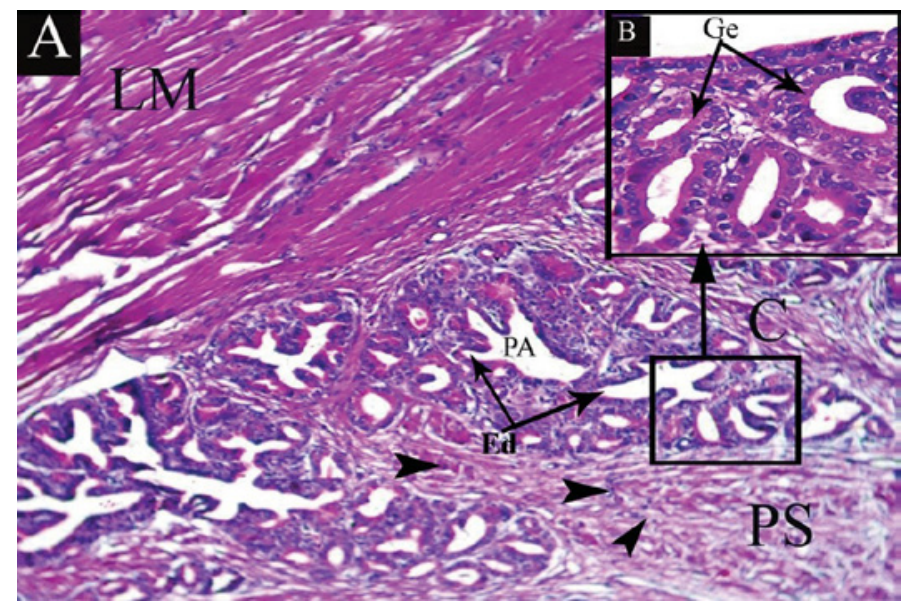

Figure 4. histological micrograph of the prostate gland (pars desseminata) from the mature buck: View (A): Lamina muscularis (LM), Prostatic acini (PA) Surrounded by fibrous capsule (C) and propria submucosa (PS) with smooth muscle bundles (black head arrows), Excretory ducts of the prostate gland (Ed). Hematoxylin and eosin (H\&E) x160. View (B): Prostatic acini lined by simple cuboidal epithelium with glandular epithelium (GE). H\&E X400.

bulbourethral gland (Fig. 1A\LB-RB; 1B/ BL; 6C/23), or Cowper gland, was similar in size to a walnut and located dorsal to the urethra on both sides, and cranial to the ischial arch. The paired bulbourethral gland is closely related to the bulb of the penis, and, in general, it appears to be covered mostly by the bulbospongiosus muscle. The right and left bulbourethral glands appear to be nearly equal in size and their shapes are also similar.

According to the histological observations, the bulboure-thral gland (Fig. 5) was surrounded by a white fibrous capsule and there were interlobular connective tissue septa that divided the gland into lobes and lobules of different sizes. The gland contained secretory units that were lined by tall 


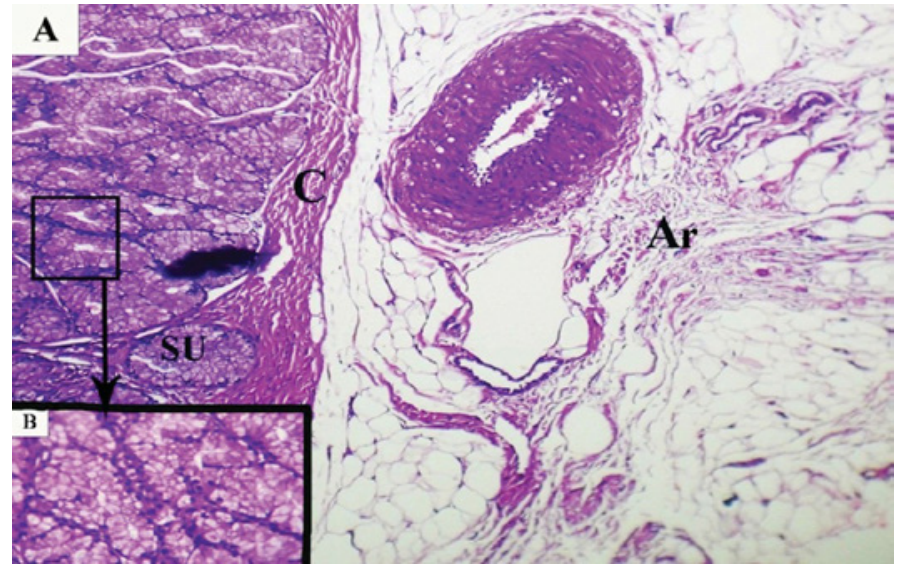

Figure 5. Histological cross section micrograph of the bulbourethral gland of the mature buck: View (A): adventitia (Ar), capsule (C) and secretory unit (SU). Hematoxylin and eosin (H\&E) x160. View (B): The lining epithelium of secretory unit is a tall simple columnar epithelium of mucous.

mucous columnar epithelium with basely located nuclei and eosinophilic cytoplasm that contained granular secretion.

\section{Discussion}

To our knowledge, there are four sex accessory glands in most mammalian species: the ampullary, the seminal vesicle, the prostate, and the bulbourethral gland, as reported in the present study. They are present in the Barki goat, horse, ${ }^{2-9}$ the bull, ${ }^{3-9}$ the spotted paca, ${ }^{4}$ the Brazilian gracile opossum (Gracilinanus microtarsus), ${ }^{5}$ the Arabian oryx, ${ }^{6}$ the elk (Cervus canadensis), ${ }^{7}$ and the red deer (Cervus elaphus). ${ }^{8}$ However, the presence of three accessory sex glands was reported by El-Hagri ${ }^{9}$ in the canine species (prostate, bulbourethral gland, and ampullary gland), canine (prostate, seminal vesicle, and ampullary gland) ${ }^{10}$ in the pampas deer (Ozotoceros bezoarticus) (prostate, vesicular, and ampullary gland),11 and in the lesser anteater (prostate, seminal vesicle, and bulbourethral gland). Finally, there are only two accessory sex glands, the prostate and the vesicular gland, in the capybara. ${ }^{14}$ Furthermore, Budras et al and El-Hagri reported that the accessory sex glands were fully developed only in the bull. ${ }^{3-9}$

The present investigation reported that the ampullary gland is a glandular enlargement of the terminal part of the ductus deferens, which is a similar result to the one mentioned by. ${ }^{9,15}$ Furthermore, Frandson et $a l^{15}$ added that its size varies within the animal species; it is well developed in the stallion, bull, and ram, but it is absent in the boar; however, El-Hagri and Bacha et al mentioned that it is ill well developed in the boar but absent in the tomcat, and also do Nascimento Lima et $a l^{5}$ reported the absence
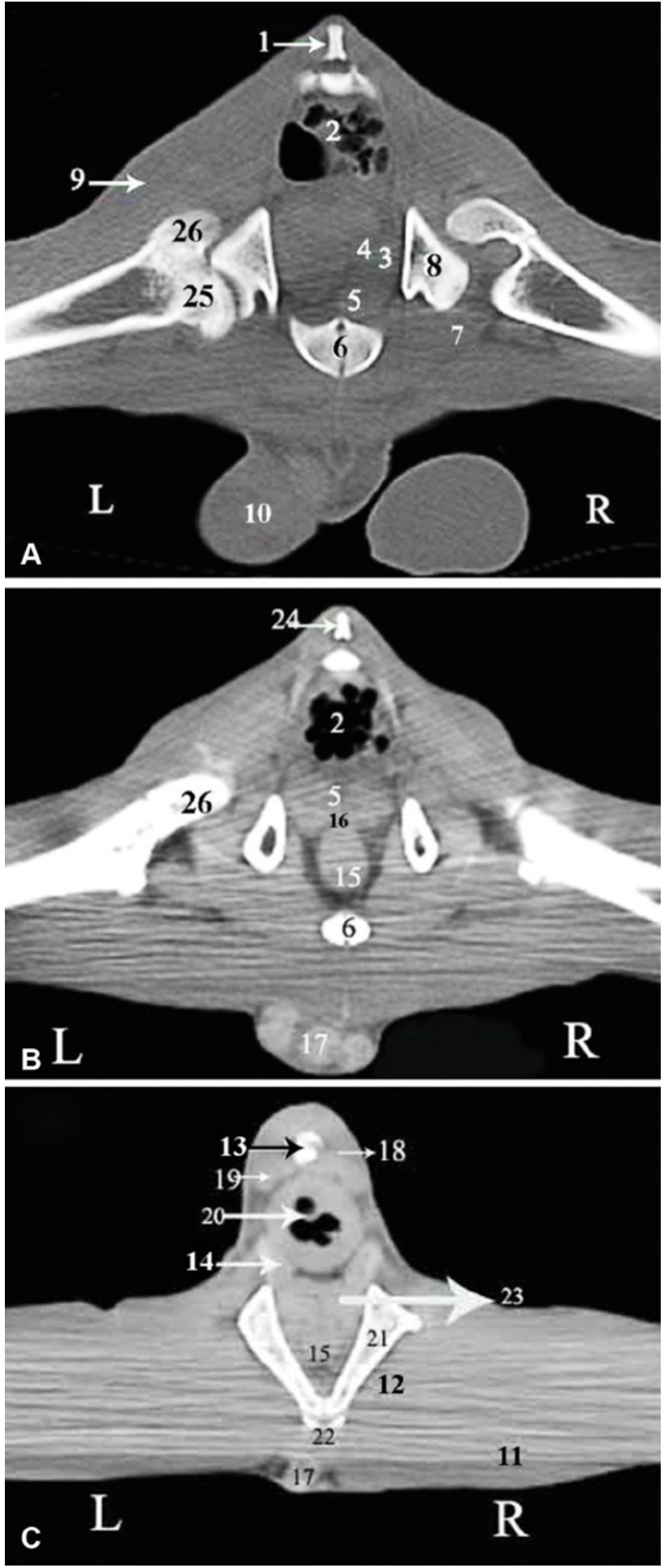

Figure 6. Computed tomography (CT) images of the male buck's pelvis; View (A) represents the transversal CT scan at the level of the the pelvic urethra and surrounded by urethral masculina, a 3rd sacral vertebra. View (B) represents the Transversal CT scan at the finding that is similar to the one obtained by $9,10,30-32$ while level of the 5th sacral vertebra. View (C) represents the transversal CT scan at the level of the 3rd caudal vertebra. 1 - 3rd sacral vertebra; 2 - Rectum; 3 - Vesicular gland; 4 - Ampulla of ductus deference; 5 - Neck of urinary bladder; 6 Pubic symphysis; 7 - Iliopsoas muscle; 8 - Right ilium shaft; 9 Superficial gluteal muscle; 10 - Testes; 11 - Right adductor muscle; 12 - External obturator muscle; 13 - 3rd caudal vertebra; 14 - Muscle sphincter ani internus and externus; 15 - Pelvic urethra; 16 - Prostate; 17- Penis; 18 - Right sacrocaudalis dorsalis lateralis muscle; 19-Right sacrocaudalis ventralis medialis and lateralis muscle; 20 - Anal canal; 21 - Right ischium; 22 - Ischiatic arch; 23 Bulbourethral gland; 24 - 5th sacral vertebra; 25 - Head of femur; 26 - Greater trochanter of femur. 
of this gland in Gracilinanus microtarsus. The present histological observations of the ampullary gland were similar to those of Trautmann et al and Wrobel, ${ }^{19,20}$ that the gland consists of three layers: the tunica mucosa, tunica muscularis, and tunica adventitia.

In all the investigated goats, the paired vesicular gland was located on the craniodorsal aspect of the urinary bladder, and it could be easily identified due to its appearance, which looks like a cluster of grapes. It is also important to note that the left vesicular gland is enlarged and higher than the right one, which is a finding similar to the one obtained by El-Hagri, Archana et al and Gofur., 921,22 The vesicular gland is the largest accessory sex gland in the bull ${ }^{3,9}$ and in the spotted paca. ${ }^{4}$ However, the vesicular gland was absent in the canines, ${ }^{9}$ Gracilinanus microtarsus, ${ }^{5}$ and in some rodents. ${ }^{23,24}$ According to the current histological studies, the vesicular gland is a lobulated alveolar gland containing a secretory unit that is lined with pseudo-stratified columnar epithelium, and the interlobular ductules are lined with stratified epithelium, while the interlobular duct is lined with simple cuboidal epithelium, a finding similar to the one obtained by Archana, Gofur, and Menezes et $a l,{ }^{22,25}$ while it was lined by simple cuboidal epithelium as reported in the spotted paca was 4 but, it was lined by a simple columnar epithelium as observed in; G. pig, ${ }^{26}$ and rat $^{27}$ and giant rat. ${ }^{28,29}$

Morphologically, the prostate gland may be single, as present in the our study and by $9,10,22,30-32$ or paired, as noted by Junqueira et al. ${ }^{33}$ In our work, we found that the single prostate gland has only the pars disseminate, which is found in the pelvic urethra and surrounded by urethral masculina, a finding that is similar to the one obtained by $9,10,22,30-32$ while Pathak et $a^{34}$ reported that there is an additional part named the corpus prostate, which is present in some gaddi goats; in contrast, this corpus prostate has not been reported in small ruminants in any of the published anatomical text books that we examined. $9,30,35$
There is some variation in the parts of the prostate gland among the animal species; the present study with ${ }^{9,10,30-32}$ noted the presence of only one part called the disseminate part, while Gofur $^{22}$ mentioned that in the Black Bengal buck the single prostate gland has two parts: the compact (external) and the disseminate (internal) parts, but in the rat, Junqueira et $a l^{33}$ noted that the paired prostate gland has a dorsal and ventral part; Neuhaus et $a l^{36}$ noted that in the G. pig the prostate gland also has two portions: the large cranial lobe and the smaller caudal lobe. Moreover, ${ }^{37}$ in the capybara noted that the prostate gland consists of three parts: intermediate, dorsal, and lateral lobes.

According to our histological studies, the prostate gland enclosed by connective tissue capsule which is thin dorsally, thick laterally and reduced in thickness ventrally. The capsule enveloped by a layer of skeletal muscle that surrounded by a layer of skeletal muscle, similar to that reported by. ${ }^{22,34}$ In the G. pig, the prostate enveloped by a fibrous muscular layer ${ }^{38}$ while, in the spotted paca, 4 this layer consists of smooth muscle fiber, similar to that observed in the prostate gland of the mouse. ${ }^{39,40}$ The present study noted that, the prostatic acini lined by simple cuboidal epithelium while, in the spotted paca, ${ }^{4}$ noted that it is simple columnar epithelium but pseudo-stratified in some regions.

Our study revealed that the paired bulbourethral gland is small in size, similar to hazelnut, and lies dorsal to the pelvic urethra and more obvious as the gland surrounded by white fibrous capsule, similar to the observations noted by., ${ }^{3,15,21,22}$ In the spotted paca, the bulbourethral gland presented at the terminal part of the rectumand dorsal to the urethra and caudal to the prostate gland. ${ }^{4}$ The bulbourethral gland is absent in the canine and present in the feline, as noted by El-Hagri and Bacha et al. ${ }^{9,18}$ The bulbourethral gland was surrounded by striated skeletal muscle, as noted by Borges et al, Gude et al and Hebel et al.,28,29 Our work mentioned that the bulbourethral gland contains secretory units that are lined with tall mucous columnar epithelium of. The lining columnar epithelium also noted by. ${ }^{29}$ The bulbourethral gland appears to be covered mostly by the bulbospongiosus muscle, and the gland itself is covered by a white fibrous capsule, similar to that noted by Budras et al. ${ }^{3}$ 


\section{References}

1. Elshennawy M. Sheep development program in Egypt. In: Gabiña D (ed.). Strategies for sheep and goat breeding. Zaragoza: CIHEAM; 27-32 (Cahiers Options Méditerraéennes; $n$. 11)1995.

2. Budras KD, Sack WO, Rock S, Horowitz A, Berg R. An.my of the Horse, Sixth Edition. Schluetersche, Germany2012

3. Budras KD, Habel RE, Wunsche A, Buda S. Bovine anatomy: An illustrated text. 1st ed. Hannover: Schlutersche GmbH \& Co. KG, Verlag und Druckerei; 34-352003.

4. Borges EM, Branco É, de Lima AR, et al. Morphology of accessory genital glands of spotted paca (Agouti paca Linnaeus, 1766). Anim Reprod Sci 2014;145(1-2):75-80.

5. do Nascimento Lima JM, Santos AC, Viana DC, et al. Estudo morfológico dos órgãos genitais masculinos em Gracilinanus microtarsus. Braz J Vet Res Anim Sci 2013;50:447-456.

6. Eljarah A, Al-Zghoul MB, Jawasreh K, et al. Characterization of male reproductive anatomy of the endangered Arabian oryx (Oryx leucoryx). Theriogenology 2012;78(01):159-164.

7. Haigh J. Reproductive anatomy and physiology of male wapiti and red deer. Current Therapy in Large Animal Theriogenology-2nd Edition. Saunders Elsevier IncSt Louis, Missouri2007:932-936.

8. Stewart DW. Male genitalia of red deer (Cervus elaphus). N Z Vet J 1983;31(07):122.9 El-Hagri MAA. Splanchnology of Domestic Animals. $1^{\text {st }}$ public organization for books and scientific publications, Giza: Cairo University Press; 23-30 Springer Berlin Heidelberg; 1967.

10. Pérez W, Vazquez N, Ungerfeld R. Gross anatomy of the male genital organs of the pampas deer (Ozotoceros bezoarticus, Linnaeus 1758). Anat Sci Int 2013;88(03):123-129.

11. Rossi LF, Luaces JP, Aldana Marcos HJ, Cetica PD, Pérez Jimeno $G$, Merani MS. Anatomy and histology of the male reproductive tract and spermatogenesis fine structure in the lesser anteater (Tamandua tetradactyla, Myrmecophagidae, Xenarthra): morphological evidences of reproductive functions. Anat Histol Embryol 2013;42(04):247-256

12. NOMINA ANATOMICA VETERINARIA. NOMINA ANATOMICA VETERINARIA. FIFTH EDITION (revised version). Prepared by the International Committee on Veterinary Gross Anatomical Nomenclature (I.C.V.G.A.N.) and authorized by the General Assembly of the World Association of Veterinary Anatomists (W.A.V.A.) Knoxville, TN (U.S.A.) 2003 Published by the Editorial Committee Hannover (Germany), Columbia, MO (U.S.A.), Ghent (Belgium), Sapporo (Japan) Springer; 2012.

13.Suvarna SK, Layton C, Bancroft JD. Bancroft's Theory and Practice of Histological Techniques, Expert Consult: Online and Print,7: Bancroft's Theory and Practice of Histological Techniques. Churchill Livingstone Elsevier; 2013.

14. Fernandez DS, Ferraz RH, Melo AP, Rodrigues RF, Souza WM. Análise histológica das glândulas uretrais da capivara (Hydrochoerus hydrochaeris). Pesqui Vet Bras 2010;30:373-377. 15. Frandson RD, Wilke WL, Fails AD. Anatomy and physiology of farm animals. John Wiley \& Sons; 2009.

16. Raghavan D. Anatomy of the ox. Indian Council of Agricultural ResearchNew Delhi 1964.

17. Sun S, Sudhakar LS, Bhardwaj RL. Seasonal Variation in the Histomorphology and Histochemistry of Ampulla of Vas Deferens of Gaddi Goat and Gaddi Sheep. Int J Morphol

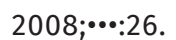

18. Bacha WJ Jr, Bacha LM. Color atlas of veterinary histology. John Wiley \& Sons; 2012.

19. Trautmann A, Fiebiger J, Habel RE, Biberstein EL. Fundamentals of the histology of domestic animals. Comstock;
1957.

20. Wrobel K. Male reproductive system. In: Textbook of veterinary histology. Edited by Dellmann H.; :1-7.DP Lea \& Febiger Philadelphia; 1993.

21. Archana P, Katiyar R, Sharma D, Farooqui M. Gerentological studies on the gross and histomorphology of the vesicular gland of Gaddi goat (Capra hircus)/Estudios gerontologicos en anatomia e histomorfologia de la glandula vesicular de cabra Gaddi (Cabra hircus). Int J Morphol 2009;27:13-21.

22. Gofur M. Anatomy and histomorphometry of accessory reproductive glands of the Black Bengal buck. Eur J Anat 2015;19:171-178.

23. Angulo JJ, Alvarez MT. The genital tract of the male conga hutia, Capromys pilorides (say). J Mammal 1948;29:277-285. 24. Gottreich A, Hammel I, Yogev L, Terkel J. Quantitative microscopic changes in the mole rat's accessory sex organs during an annual cycle. Anat Rec 1996;246(02):231-237.

25. Menezes DJ, Assis Neto AC, Oliveira MF, Farias E. Morphology of the male agouti accessory genital glands (Dasyprocta prymnolopha Wagler, 1831). Pesqui Vet Bras 2010;30:793-797 26. Wagner JE. The biology of the guinea pig. Academic Press; 2014.

27. Sprando RL, Collins TF, Black TN, et al. Light microscopic observations on the reproductive tract of the male sand rat, Psammomys obesus. Tissue Cell 1999;31(01):99-115.

28 Gude WD, Cosgrove GE, Hirsch GP. Histological Atlas of the Laboratory Mouse. Springer; 1982:17-19

29. Hebel R, Stromberg MW. Anatomy and embryology of the laboratory rat. BioMed Verlag; 1986.

30. Getty R. The Anatomy of the Domestic Animals. Vol.1, 5th Ed. W.B. Saunders CompanyPhiladelphia, USA1975.

31. Garrett PD. Guide to ruminant anatomy based on the dissection of the goat. Low state university press AMES; 1988. 32. Kundu P. Anatomical studies on the accessory male sex glands (gross and microscopic) of the Indian goat (Jamunapari and cross Jamunapari). Indian J Anim Health 1980;19:151-153. 33. Junqueira LCU, Martins EO, Luiz Carlos Uchôa Junqueira EO. Atlas de anatomia microscópica do rato1947.

34. Pathak A, Katiyar R, Sharma D, et al. Gross anatomical, histological and histochemical studies on the postnatal development of the prostate gland of Gaddi goat. Int J Morphol 2012;30:731-739

35. Dyce KM, Sack WO, Wensing CJG. Text book of Veterinary anatomy.

W.B. Saunders CompanyPhiladelphia, London and Toronto2010 36. Neuhaus J, Dorschner W, Mondry J, Stolzenburg JU. Comparative Anatomy of the Male Guinea-Pig and Human Lower Urinary Tract: Histomorphology and Three-Dimensional Reconstruction. Anat Histol Embryol 2001;30:185-192.

37. Ojasti J Estudio biológico del chigüire o capibara: Fondo Nacional de Investigaciones Agropecuarias Caracas; 1973

38. Amiya PSH, Maiti BR. Quantitative studies of the reproductiveor-gans of the male bandicoot rat - A common rodent pest. Ana- tAnzeiger 1982;151:483-495.

39. Kawamura H, Nonogaki T, Yoshikawa K, Kimura M, Ichihara I, NakanoT. Morphological changes in mouse accessory sex glands following neonatal estrogen treatment. Ann Anat

2000;182(03):269-274.

40.Cagnon VHA, Camargo AM, Rosa RM, Fabiani R, Padovani $C R$, Martinez FE. Ultrastructural study of the ventral lobe of the prostate of mice with streptozotocin induced diabetes (C57BL/ 6J). Tissue Cell 2000;32(04):275-283. 
Received: 16/Feb/2019

Accepted: 14/Aug/2019
Corresponding author

Mohamed M. A. Abumandour

Email: m.abumandour@yahoo.com 